\title{
Ignoring the sacroiliac joint in chronic low back pain is costly [Corrigendum]
}

Polly DW, Cher D. Clinicoecon Outcomes Res. 2016;8:23-31.

The authors would like to make a correction to the Disclosure statement. The corrected statement is as follows:

David Polly is an investigator in clinical research studies sponsored by SI-BONE but has no financial interest in the company. Daniel Cher is an SI-BONE employee. SI-BONE sponsored the clinical trial from which data were used in the reported model. SI-BONE manufactures the implant used in the SIJF surgery studied. The authors report no other conflicts of interest in this work.

\section{Publish your work in this journal}

ClinicoEconomics and Outcomes Research is an international, peerreviewed open-access journal focusing on health technology assessment, pharmacoeconomics and outcomes research in the areas of diagnosis, medical devices, and clinical, surgical and pharmacological intervention. The economic impact of health policy and health systems organization also constitute important areas of coverage. The manuscript management system is completely online and includes a very quick and fair peer-review system, which is all easy to use. Visit http://www.dovepress.com/testimonials.php to read real quotes from published authors. 